\title{
The Role of Foreign Policy and its Purpose in World Politics
}

\author{
İsa Erbaş
}

\author{
PhD candidate, Department of Political Science and International Relations \\ European University, Tirana, Albania \\ E-mail: isaerbas@gmail.com
}

\section{Doi:10.5901/ajis.2013.v2n11p40}

Abstract

This research paper examines the role of foreign policy and its purpose in world politics. Since the 1990s, foreign policy has started facing challenges of constant redefining its places of responsibilities. It is well known that domestic politics is simply an essential part of the explanation for states' foreign policies, and it searches to understand its impact in world politics. Mainly, foreign policy analysis based upon the argument that all decisions between nations are taken by single or group decision makers. External and domestic factors have affected foreign policy 'decisions. World leaders make decisions to go to war, make peace, create atmosphere for diplomatic relations, impose economic sanctions etc. It is important to note that this research adapts quantitative and content analyses. Firstly; this study begins defining identity. It shows that how much identity is important for foreign policy. Secondly, the study gives information about background of foreign policy and the advantages of foreign policy in world politics. Thirdly it explains the purpose of foreign policy in the World. During the whole research and after the completion of the research, the researcher should abide by the ethical code of The Economic and Social Research Council (ESRC).The SPSS 16, and the Nvivo10 were used to find and analyze the collected data.Finally, the paper concludes its findings and results with discussions and further suggestions.

Keywords: Foreign policy, purpose, world politics, identity, national interest.

\section{Introduction}

In the political science and international relations, in order to understand the foreign policy we need to investigate and examine situations in a more appropriate and exact ways and to be able to evaluate and approach realities. We should look at the foreign policy through different views, including economic, social, state identities, national interests, cultural, historical and psychological factors.

We know that such views are beyond our understanding and perception and even beyond our mental potential. We need necessary tools in order to do right research and get right results.

We need to focus on all the internal and external factors so we can analyze the issues. Apart from these, we have to concentrate on ideals and material interests. In this study I have examined and analyzed the role of identity in the foreign policy. The foreign policy includes the historical, cultural and economic ties with states. National interest based and state identity based models of the foreign policy lead to huge benefits based on particular accounts of state interests.

After the Cold War it was necessary to make a complete change not only in the international system but also in the foreign policy. That is why; international actors had to examine their systems and policies one more time. Consequently, the debate about national identity, and national interest, and the kind of political, economic, and social systems that states should adopt. The aim of the foreign policy should be to build closer relationship with other states in order to preserve security, peace, and stability. Any crisis and conflicts in the states influence each other.

\section{Literature Review}

In order to analyze the foreign policy it is necessary to use the constructivist approach. This approach is important for the foreign policy, because this constructivist approach involves state identity, national identity and interests, national security, and it has a peaceful impact on the foreign policy. So constructivism in the foreign policy is united with my study. Constructivism also involves internal and external identities and norms. So foreign policy is understood and analyzed through constructivism.

In the foreign policy analysis constructivism plays an important role.The rise of constructivism has sparked a renewed interest in international history (Scott Burchill, 2005, p.206). Constructivism constitutes an alternative research 
program to the study of international politics and foreign policy (Bozdaglioglu, 2003, p.22). Constructivism, therefore, holds the view that international actors are embedded in a structure that is both normative and material, and allows for the possibility that under the proper conditions actors can generate shared identities and norms that are tied to a stable peace" (Barnett, 1998,p.10).

In the foreign policy international politics is very important and at the same time it is very sensitive. As wendt says that the social structure of international politics is thinner and simpler than that of domestic politics (Wendt, Dec.1998).Once one deals with the foreign policy should mind the social structure of international politics.

Bozdaglioglu argues that unlike domestic political systems, international systems are decentralized and hierarchic. For this reason, anarchy is the ordering principle of the system. He also states that in order to survive in this anarchic world, states should take care of themselves (Bozdaglioglu, 2003 p.13). In order to survive in world politics, foreign policy is very important for the states.

Ruggie argues:

It is striking how anachronistic these characterizations seem today for foreign policy making in the industrialized parts of the world (Ruggie, 1998 p.158).

According to Wendt academic students of international politics today as positivists think they can get closer to the truth about international politics, only if the methods are followed which have proven so successful in the natural sciences (Wendt, Dec.1998). That is why in order to get the truth we have to follow the methods.

According to Adler:

Constructivism broadens our understanding of the relationship between scientific knowledge and International Relations outcomes with the argument that International Relations in general, whether cooperative or conflict, are framed and socially constructed by all classes of knowledge, scientific and other. (Adler,2005,p.108).

There are some factors that affect the role of foreign policy in international relations. The factors are: identity,collective identity,political identity, national identity and state identity.These identities are very important for the foreign policy.

\section{Method of the Study}

This study has two parts. First part is about general information of the role of foreign policy and its purpose in world politics. This information has been taken from secondary sources. The sources have been treated documents as a source of the study. The second part of the study is an empirical study. The data was collected from the survey that was conducted in Albania.

\section{Identity}

Identity is very significant in the foreign policy analysis. Identity shapes foreign policy preferences, interests and behavior. Bozdaglioglu claims that mutual construction is very important for identities and he says that in order for states to hold and maintain a social identity requires acceptance and approval from others because identities are mutual constructions (Bozdaglioglu, 2003,pp.86-87).

"Identity is not a fact of society; it is a process of negotiation among people and interest groups. Identity describes the society and society is constituted by identity" (McSweeney, 2004,pp.73-74). The role of identity in negotiating the new international order would be fully justified (Kupchan, 2001, p.39). Identity and nationl interests can not be seperated.Wheeler claims that identity leads to particular conceptions of the national interest (Wheeler, 2008,p.17).According to Asano: "the concept of identity, whether it is of an ethnic or a religious community, on the other hand, loaded with emotion and spoken of in terms of material objects and manners of life" (Asano, 2005,p.34). In every country decision-makers' special sense of their own national history, identity and interests set the tone for the various patterns that are to characterize the aid discourses of countries during the ensuing decades. (Veen, 2011,p.78). "The advent of the constructivist school has helped remedy this shortcoming by putting ideas and identity at the center of scholarly inquiry. The most fruitful line of inquiry entails examining how power, institutions, and ideas and identity together shape outcomes" (Kupchan, 2001, p.8).

Barnett argues: 
Most definitions of identity, as they say, begin with the understanding of oneself in relation to others .A political identity is an actor's experience of a shared social relation in which at least one of the parties including third parties is an individual or organization others (Barnett, 1998,p.400).

Wendt argues that,the structures of human association are determined primarily by shared ideas rather than material forces. The identities and interests of purposive actors are constructed by these shared ideas rather than given by nature (Wendt, 1999,p.1). Cultures are also important for identity because cultures shape individual identity (Smits, 2005,p.12).Smits goes further saying that identity was shaped by "national character" as well as class and social position (Smits, 2005,p.5). McSweeney says that we live in a culture of fluid identities a feature of modernity and identity is an idea in search of a person (McSweeney, 2004,p.162). McSweeney goes further claiming that, identity is a social act as well as a structure of meaning (McSweeney, 2004,p.165). Identity politics have given a sharper and often destructive twist to struggles for cultural recognition (Loescher, 2011,p.99). The significance of identity will provide principles fit to preserve cultural contexts which are necessary for the preservation of identity (McKinnon, 2002,p.11).

Bozdaglioglu claims:

Each organization's culture shapes their identity conceptions that in turn shape their foreign policy preferences and understanding of the national interest. States, depending on the allocation of power among different groups, organizations, may represent one of the social identities in the system (Bozdaglioglu, 2003, p.158).

According to Katzenstein identity is that people often come to identify with a group of others because people share common interests. An identity acts as a cultural frame that tells us who we are and how we ought to act (Katzenstein, 2009,p.138). Yurdusev says that, identity, comes from its being with others, not just from others (Yurdusev, 2003,p.50).Another author describes identity as a central need of individuals but a need that can be met without conflict. That identity often seems a source of conflict is misleading.He continues saying that it is a use of state power to buttress an identity that creates conflict (Hilkermeier, 2004, p.65).

Barnett argues:

Identities, in short, are not only personal or psychological, but are social, defined by the actor's interaction with and relationship to others; therefore, all political identities are contingent, dependent on the actor's interaction with others and place within an institutional context. It is mainly a social identity that generates a positive identification between peoples of members states (Barnett, 1998, p.47).

\section{Background of Foreign Policy and the Advantages of Foreign Policy in World Politics}

It is very important to give information about foreign policy in order to understand and evaluate its role in world politics. I need to explain the world foreign policy`s purpose. I have also given information about three important states` foreign policy`s purpose in the world, namely U.S., China, and Russia. The information will also enlighten and help compare a country's foreign policy with those states' foreign policy. All Political groups within a state do not simply affect world politics through the influence they may have on their own state's foreign policy. How foreign policy is made among states?

\section{According to Bull:}

Firstly, they may enter into relations with political groups in other states; business enterprises, trade unions, political parties, professional associations, churches, all have their being partly within the transnational. Secondly, they may enter into relations with foreign states, as when a multinational corporation enters into an agreement with a host government, political groups engage in a protest outside a foreign embassy, or revolutionary groups in one country assist their coideologists in another to overthrow the government. Thirdly, they may enter into direct relations with an international organization. (Bull, 2002, p.267).

Waltz argues that, if there is a state there should be foreign policy, and in foreign policy the state must speak with a single voice (Waltz, 2001, p.179). Bukovansky claims that, states in the Eighteenth-century were far more oriented toward international relations and foreign policy than the states now (Bukovansky, 2002, p.62).So we can see that foreign policy plays more important role in our time than in the past. Since the early 1990s because of globalization threat, foreign policy started facing manifold challenges of continually redefining its spaces of accountability (Chong, 2007, p. 2). Marsh claims that, according to realists, foreign policy in terms of the states, attempts to maximize security through power. For instance, force, diplomacy, duplicity, balancing power, and conduct contrary to democratic principles are all options to be 
explored in the prudent pursuit of national security (Marsh, 2001, p.3). The main aim of foreign policy has been seen as a pursuit of the national interest in the external relations of states. National interest mainly involves in economic well-being, political values and security (Marsh, 2001, p.1). For example, regarding economic situations, foreign policy first emerged in U.S. following the First World War, because of the growing importance of oil to modern industrial society and modern warfare, fear of exhaustion of U.S. domestic reserves, and the need of U.S. companies with foreign markets for additional sources of supply (Elizabeth Cobbs Hoffman, 2002, p.6). John J. Mearsheimer argues that "U.S. foreign policy shapes events in every corner of the globe" (John J. Mearsheimer, 2006, p.1).

There are many factors behind foreign policy. The factors can affect foreign policy in both short and long run such as: International, domestic, cultural, and social changes (DeRouen, 2010, p.10). These factors all affect nations.For instance, foreign policy decisions have very important consequences for nations, their allies, and rival countries. Even the decisions can affect the survivability of leaders in power (DeRouen, 2010, p.25).When the leaders, who are in power, make decisions about foreign policy, the decisions will affect their future. The leaders can change world order by making a proper foreign policy.Scott Burchill claims that "liberal internationalists were naively optimistic about the prospects for a new world order based on the rule of law, open diplomacy and collective security, and they thought their ideas were dangerous because they distracted attention from the main task of foreign policy which is to ensure the security and survival of the state" (Scott Burchill, 2005,p.86).

We can say that there are many advantages of foreign policy. Through foreign policy "states recognize each other's sovereignty tend not to conquer each other, not because they cannot, but because recognition implies a willingness to live and let live" (Wendt, 1999,p.209). This kind of ideology is effective in foreign policy decisions. It is a function of the construction of state identity and the international environment in which a state interacts (Uzer, 2011, p.6).Starr supports Wendt and Uzer by saying:

\begin{abstract}
States that share common security interests have strong incentives to avoid severe conflicts among themselves in order to ensure cooperation against a common security threat. Whereas some states are able to rely largely on their own diplomatic and military means to achieve foreign policy goals, often states find it necessary to form alliances to counter international threats (Starr, 2006, p.18).
\end{abstract}

For this reason, conceptions of corporate responsibility highlights the possibilities for the moral exercise of agency, as references to international and humanitarian responsibilities for good international citizenship which is concerned with the foreign policy of states (Andrew Linklater, 2006,p. 257). Thomson makes sure that as with all foreign policy, words have to be backed by deeds. It means that state's commitment to human rights in the external environment, requires more than just rhetoric (Thomson, 2008, p.170).

\title{
6. Purpose of Foreign Policy in the World
}

I will mainly deal with the purpose of foreign policy in the world. We can also ask such a question. What are the main factors behind the foreign policy? Some authors say the purpose is economy. Some say national interest and some say stability and peace. Even some say the leaders, who are in power, make sure to strengthen their power. Here I will give some examples of some countries ` foreign policy aims. Drezner explains so clearly the purpose of foreign policy.He says "foreign policy leaders conceive of a national interest defined as maximizing their welfare and the security of that welfare. To further their interests, states will usually act to increase their own income and wealth" (Drezner, 1999, pp. 28-29).Elias claims that realists think that the permanent rivalry of states whose foreign policy focuses on their national interest is a permanent feature of the international system and it is a constant reordering of the balance of power. It is an only form of stability available in a system where sovereign independence is considered as stability (Elias, 2007, p.54). Foreign policy is also believed that, through commercials a state's international position might be strengthened or it might serve to strengthen its export industries (Veen, 2011,p.37). Andrew Linklater underlines the importance of foreign policy against terrorist organization. He argues that "the analysis of good international citizenship reflects the fact that foreign policy has to deal with such diversity which now includes the threats that a new distinct breed of terrorist organization poses to national and personal security" (Andrew Linklater, 2006,p. 231).So to live in this world peacefully, foreign policy is very important for us.

There are some factors for reliability of foreign policy which are necessary in order to reach its purpose.Foreign policy depends on force, lower level coercion, flexible negotiations so that to achieve its goals (Marsh, 2001, p.14).The purpose of foreign policy varies from state to state. "Many moral foreign policy objectives pose no risk to national survival. And other national interests simply do not have the ethical priority of survival" (Scott Burchill, 2005,p.51). Some states 
have various conceptions of their national goals and interests, and that these varieties form policy choices (Veen, 2011, p.23). Some states "which cede economic sovereignty to these global players in the name of free trade and commerce therefore run the risk of elevating private commercial gain to the primary foreign policy objective of the state" (Scott Burchill, 2005, p.77). Apart from national interests and identities for some states human rights were considered a peripheral and even inappropriate topic for foreign policy. Today, in many countries, their foreign policy involve in human rights. Many questions still remain unanswered about to what degree human rights concerns affect foreign policy decisions, and whether such human rights policies actually improve domestic conditions in the target country or not (Handbook of International Relations,2002, p.702).

Bull argues:

To say that a state's foreign policy should be based on pursuit of the national interest is to insist that whatever steps are taken should be part of some rational plan of action; an approach to foreign policy based on the national interest may thus be contrasted with one consisting simply of the uncritical pursuit of some established policy, or one consisting simply of unconsidered reactions to events (Bull, 2002, p.64).

Now I will examine the purpose of foreign policy of U.S.A., China and Russia. Firstly let's start with U.S.A. foreign policy. U.S.A. foreign policy went little beyond making mostly commercial treaties, sending out and receiving ambassadors, and protecting overseas trade in the late eighteenth century (Davidson, 2009, p.26). "The U.S. national interest should be the primary object of American foreign policy" (John J. Mearsheimer, 2006,p.1).American foreign policy can be examined from different perspectives such as historical, institutional analysis, issue area examination, rational choice theory, and study of ideational and legal evolution, gendered perspectives. Real politic accounts are all valid and useful approaches in order to understand not only American foreign policy but also the foreign policy of any nation (Elizabeth Cobbs Hoffman, 2002, p.426).In 1991 Bush administration marketed the first Gulf War stating that it was about jobs, oil and economic security. So in order to access valuable natural resources can shape U.S.A. foreign policy. It can be said that foreign policy decisions are often influenced by the state's economic interests (DeRouen, 2010, p.130).We can come into conclusion that economic intersets of a state take first place in foreign policy.

According to Streich:

For presidents and other actors who take a Hamiltonian view of U.S. foreign policy, the economy should guide American foreign policy because the national interest is interconnected with national economic well-being. Further, international capitalism leads to world peace because it enhances the interconnectedness of nations through trade (Streich, 2011, p. 15).

Davidson claims again that "in essence, U.S.A. foreign policy Formulating Foreign Policy in a Autocracy in Central America had long ago been privatized by the economically oriented special interests that represent businesses such as United Fruit / Chiquita Brands. It is their parochial interests that had come to define the U.S. national interest in this part of the world" (Davidson, 2009, pp.50-51).We have seen different types of foreign policy in Obama administration. He has changed American foreign policy perception and set a foreign policy course that has revitalized the image of the United States as a global leader. He has mainly focused on high ideals of diplomacy, multilateralism, and peace with a willingness to deploy and use military force, such as in Afghanistan or against pirates off the coast of Somalia. President Obama has established a "liberal realist" approach to foreign policy (Streich, 2011, p. 277).

In 1950s the aim of the Communist China's foreign policy was to rely mainly on the traditional and basic factors determining the international behavior of nations, such as national security, geography, or resources (Levi, 1953,pp.280281).Apart from that aim according to Shichor, between 1950 - 1955 there were six countries which recognized China as early as 1950 but did not establish diplomatic relations. The countries were Britain, Ceylon, Norway, Israel, Afghanistan and the Netherlands. One of China's main foreign policy aims during that period was to set up normal relations with those countries so as to expand China's network of diplomatic representation (Shichor, 1979, p.22). After the cold war period China made changes in its foreign policy which is to maintain stable but high growth rates through market-led and also economic reform. Another purpose of foreign policy is defense of national sovereignty (Swaine, 1995,p.81).Towards 2000 ,China tried to consolidate its regime stability partly through foreign policy in order to protect its national interest (Kupchan, 2001, p.58).

After the break of communist regime in Russia, Russian`s foreign policy`s purpose was to revive Russia as a democratic, free state; to provide favorable conditions for the formation of a modern efficient economy which aimed to guarantee Russian citizens a worthy standard of living, and the country financial and economic independence (Andrei Melville, 2005, p.27). Another aim of Russian foreign policy was "the Russian political class continued to view foreign 
policy in predominantly geopolitical terms. In the immediate aftermath of the Soviet collapse, there was much talk in Russia and the West about the obsolescence of geopolitics and the corresponding primacy of economic objectives" (Lo, 2002, p.7). During Putin`s period, Russia under Putin and Medvedev has been more effective at pursuing an independent foreign policy has been its remarkable economic transformation since 2000 (Mankoff, 2009, p.33).If it is compared with its early years before 2000 , Russia has made very important progress in its foreign policy.

\section{Main Actors and Factors in the Foreign Policy Making Process}

Who are the main factors and actors behind the policy making decision process? I will start to enlighten this question. Foreign policy decisions are shaped by many factors. "The real world is complicated, and many variables are taken into account when decisions are made. The role of information processing, framing, and cognitive biases in decision making points to the need for a psychological approach to FPDM" (DeRouen, 2010, p.97). Stoessinger claims that men and women make foreign policy decisions (Stoessinger, 2011, p.418).

Chong argues:

Foreign policy is conducted in an environment of multiple linkages between home and abroad in the forms of NGOs, MNCs, academics, political leaders, interventions of several foreign governments, as well as intense media scrutiny (Chong, 2007, p. 5).

According to Uzer there are three actors behind policy making decisions. This is mainly in Turkish foreign policy making. These are three institutions responsible for formulating foreign policy are the prime minister, the foreign ministry and the military. The foreign ministry provided the expertise on foreign affairs and was responsible for the daily running of foreign policy. It would offer the government alternative options on a particular policy area and would help it to come to its ultimate decision (Uzer, 2011, p.76).Uzer also goes further by saying that the government plays very important role and it is the most influential in foreign policy making, the public, the foreign ministry and the army also play important role in making foreign policy (Uzer, 2011, p.11). In the past military was very effective in Turkish foreign policy making but now it does not involve much in making foreign policy process.

DeRouen argues:

International, Domestic, and Cultural Factors Influencing Foreign Policy Decision Making Foreign policy decisions are typically made in a strategic setting. Thus, behaviour of adversaries and allies affects foreign policy decisions in an interactive sequential setting (DeRouen, 2010, p.121).

Siniver also agrees with above mentioned ideas and he claims that personalities played especially an essential role in the shaping of the nature and outcome of the decision-making process, the making of foreign policy, especially during international crises (Siniver, 2008, p.43). Besides the mentioned factors international system factors are also playing important role in foreign policy making. For instance, "the Soviet threat to the territorial integrity of Turkey necessitated closer ties with the United States. While containment of the Soviet Union was a top priority for Turkish policy makers, the eruption of the Cyprus dispute redirected its concerns towards Cyprus" (Uzer, 2011, p.75).Policy making factors and actors are changed from situation to situation. According to Scott Burchill, realists claim that foreign policy imposed by the special office of the statesman (Scott Burchill, 2005,p.50). The nature of global information space is also another factor in making foreign policy. Thus the aim of defending security, identity, and community cause to make foreign policy (Chong, 2007, p. 4).

There are also other strategies for policy making leaders for political leadership. The domestic and external environments proactively use different tools in leadership process in policymaking. These tools are called strategies (Grove, 2007,p.2).When foreign policy makers make decisions they need "to look inside at domestic politics elections, public opinion, the bureaucracy, and many other internal factors as well as international factors that influence foreign policy decisions deterrence, the arms race, the regime type of the adversary, and so on" (DeRouen, 2010, p.62). Otherwise the foreign policy makers can fail in decision making and taking process. DeRouen again goes further: "leaders who make foreign policy decisions should take into account not only how their policies will be viewed at home but how their signals of action and inaction, peace overtures, threats to use force, and attempts at reconciliation will be interpreted by their opponents and other states" (DeRouen, 2010, p.145).

I conducted a survey in Albania about foreign policy. I asked the same question 716 people in different Albanian cities mainly: Tirana, Shkoder, Kaveje, Kruje, Lushnije and Durres. I tried to conduct this survey with educated people, 
particularly, who were studying in the universities or who graduated from the universities. The main purpose of this survey was to know how much Albanian people were interested in foreign policy.

Figure 1. Which event are you most interested in? (Frequency)

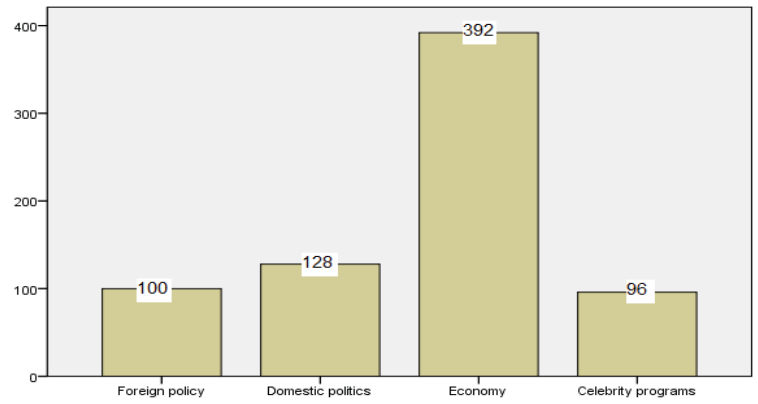

Figure 2. Which event are you most interested in? (Percent)

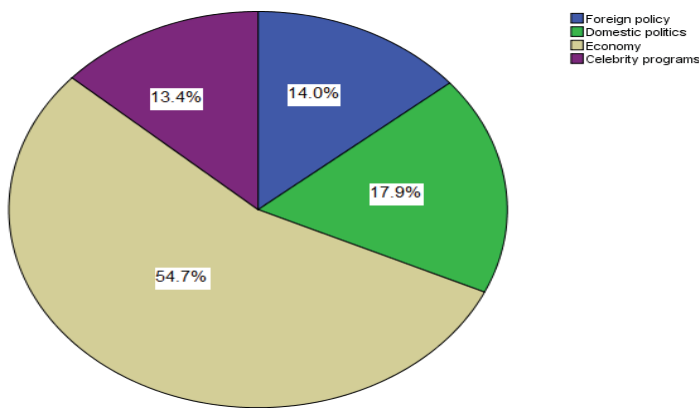

It is shown in the figure 1 and 2 that not many respondents, 14 percent or 100 out of 716 , state that they are interested in foreign policy. The majority of respondents, 54.7 percent or 392 out of 716 are interested in economy. This survey shows that people lack of interests in foreign policy.

\section{Conclusion}

The foreign policy in international relations is the means that help all states interact with foreign nations and they also have the possibilities to have interactions with organizations, corporations and individual citizens.As it has been observed that, foreign policy declined in importance toward the end of this period and throughout the 19th century and the nations have focused more on domestic expansion and domestic trade. In international relations, the foreign policy towards states is very important. Especially the foreign policy is very essential for the neighboring regions and it is necessary to improve the relations through foreign policy. We can shortly say that the foreign policy is a tool for countries in order to improve their relations with all states. We have witnessed that states pay more attention to tools of foreign policy namely, cultural and economic perspective and 'political-strategic perspective. In order to achieve all of these, the states need also time and work with other countries and statesmen.

\section{References}

Adler, E. (2005). Communitarian International Relations. London and Newyork: Routledge.

Andrei Melville, T. S. (2005). Russian Foreign Policy in Transition. New York: Central European University Press.

Andrew Linklater, H. S. (2006). The English School of International Relations. Cambridge: Cambridge University Press.

Asano, A. (2005). Community-Identity Construction in Galatians. London: T\&T Clark International.

Barnett, E. A. (1998). Security Communities. Cambridge: Cambridge University Press. 
Bozdaglioglu, Y. (2003). Turkish Foreign Policy and Turkish Identity. New York and London: Routledge.

Bukovansky, M. (2002). Legitimacy and Power Politics. Princeton: Princeten university press.

Bull, H. (2002). The Anarchical Society. New York: palgrave.

Chong, A. (2007). Foreign Policy in Global Information Space. New York: Palgrave - Macmillan.

Davidson, L. (2009). Foreign Policy, Inc Privatizing America's National Interest. Kentucky: The University Press of Kentucky.

DeRouen, A. M. (2010). Understanding Foreign Policy Decision Making. Cambridge: Cambridge university press.

Drezner, D. W. (1999). The Sanctions Paradox, Economic statecraft and international relations. Cambridge: Cambridge university press.

Elias, P. S. (2007). International Relations, the Basics. London: Routledge.

Elizabeth Cobbs Hoffman, N. C. (2002). Encuclopedia of American Foreign Policy, Vol.3. New York: Charles Scribner's Sons.

Elizabeth Cobbs Hoffman, N. C. (2002). Encyclopedia of American Foreign Policy, Vol.1. New York: Charles Scribner's Sons.

Grove, A. K. (2007). Political Leadership in Foreign Policy. New York: Palgrave Macmillan.

Handbook of International Relations . (2002). London: Sage.

Hilkermeier, M. A. (2004). Observing International Relations. London: Routledge.

John J. Mearsheimer, S. M. (2006, March 23). The Israel Lobby and U.S. Foreign Policy. Retrieved March 24, 2013, from www.Irb.co.uk Katzenstein, J. T. (2009). European Identity. Cambridge: Cambridge University Press.

Kupchan, C. A. (2001). The peaceful change of international order. Tokyo: United Nations University Press.

Levi, W. (1953). Modern China's Foreign Policy. London: Oxford university press .

Lo, B. (2002). Russian Foreign Policy in the Post-Soviet Era. New York,: Palgrave Macmillan.

Loescher, A. B. (2011). Refugees in International Relations. Oxford: Oxford University Press.

Mankoff, J. (2009). Russian Foreign Policy. New York: Rowan and Littlefield.

Marsh, A. P. (2001). US Foreign Policy since 1945. London: Routledge.

McKinnon, C. (2002). Liberalism and the Defence of Political Constructivism. New York: Palgrave.

McSweeney, B. (2004). Security, Identity and Interests,A Sociology of International Relations. Cambridge: Cambridge University Press.

Ruggie, J. G. (1998). Constructing the World Polity. London: Routledge.

Scott Burchill, A. L.-S. (2005). Theories of International Relations. New York: Palgrave Macmillan.

Shichor, Y. (1979). The Middle East in China's Foreign policy. Cambridge : Cambridge University Press .

Siniver, A. (2008). Nixon, Kissinger, and U.S. Foreign Policy Making. Cambridge: Cambridge university press.

Smits, K. (2005). Reconstructing Post-Nationalist Liberal Pluralism From Interest to Identity. New York: Palgrave Macmilan.

Starr, H. (2006). Approaches, Levels, and Methods of Analysis inInternational Politics. New York: Palgrave Macmillan.

Stoessinger, J. G. (2011). Why Nations Go to War. Boston: Wadsworth.

Streich, A. K. (2011). U.S.Foreign Policy. Oxford: Greenwood.

Swaine, M. D. (1995). Domestic Change and Foreign Policy. Santa Monica: Rand.

Thomson, A. (2008). U.S. Foreign Policy Towards Apartheid South Africa, 1948-1994. New York: Palgrave Macmillan.

Uzer, U. (2011). Identity and Turkish Foreign Policy. London: I.B.Taurus.

Veen, M. v. (2011). Ideas, Interests and Foreign Aid,Cambridge Studies in International Relations. Cambridge: Cambridge University Press.

Waltz, K. N. (2001). Man, the State and War. New York: Columbia University press.

Wendt, A. (1999). Social Theory of International Politics. Cambridge: Cambridge University Press.

Wendt, A. (Dec.1998). On Constitution and Causation in International Relations. Review of International Studies, Vol. 24, The Eighty Years' Crisis 1919-1999, 101-117.

Wheeler, J.-M. C. (2008). National interest and international solidarity. Tokyo: United Nations

Yurdusev, A. N. (2003). International Relations and the Philosophy of History. New York: Palgrave. 